\title{
Effects of Changes in Cell Size and Ouabain Sensitive Respiration on Development of Brown Adipose Tissue Thermogenesis in the Rabbit
}

\author{
ALAN H. KLEIN ${ }^{(22,23)}$ AND DELBERT A. FISHER \\ Perinatal Research Laboratories, Department of Pediatrics, Harbor-UCLA Medical Center, UCLA School of \\ Medicine, Torrance, California, USA
}

\section{Summary}

Basal brown adipose tissue (BAT) cell respiration increased significantly from 24 days gestation to 10 days postnatal age and demonstrated a significant positive correlation with cell size $(r=$ $0.93, P<0.01$ ). After adjustment for variation due to cell size, basal respiration at 24 and 31 days fetal age were not significantly different $(P>0.05)$, whereas basal respiration at 10 days postnatal age was greater than that in either of the two fetal groups $(P<$ 0.025). Ouabain did not have a consistent suppressive effect on basal respiration. Catecholamine-stimulated respiration increased significantly from 24 to 31 days gestation with no further increase at 10 days of postnatal age. Although there was a significant correlation between stimulated respiration and cell size $(r=0.92$, $P<0.01$ ), adjustment for cell size did not change this pattern of development.

Mean ( \pm S.E.) ouabain suppression of catecholamine-stimulated respiration increased from $42.8 \pm 4.4 \%$ at 24 days gestation to $61.9 \pm 2.9 \%$ at 31 days $(p<0.001)$ and $69.9 \pm 1.6 \%$ at 10 days postnatal age. Stimulated respiration independent of sodium-potassium transport (respiration in the presence of ouabain) varied from a mean of $24.0 \pm 4.3 \mu \mathrm{l} \mathrm{O} / 10^{6}$ cells $\bullet h$ at 24 days of age to $312 \pm 41 \mu \mathrm{lO}_{2} / 10^{6}$ cells $\bullet \mathrm{h}$ at 31 days $(P<0.001)$ and $250 \pm 24$ $\mu \mathrm{l} \mathrm{O}_{2} / 10^{6}$ cells $\cdot h$ at 10 days postnatal age. Sodium-potassium transport dependent respiration (e.g., the difference between total stimulated respiration and respiration in the presence of ouabain) increased from $17.8 \pm 3.6 \mu \mathrm{l} \mathrm{O} / 10^{6}$ cells $\bullet h$ at 24 days to $533 \pm$ $104 \mu \mathrm{l} \mathrm{O}_{2} / 10^{6}$ cells $\cdot h$ at 31 days and $561 \pm 51 \mu \mathrm{l} \mathrm{O} \mathrm{O}_{2} / 10^{6}$ cells $\bullet h$ at 10 days postnatal age. For both sodium-potassium dependent and independent respiration measurements, mean results in the 31 day fetal and 10 day postnatal animals were similar and significantly greater than the measurements for $\mathbf{2 4}$ day fetal animals $(P$ $<0.01$ ).

These results suggest that the increase in basal BAT respiration in the rabbit during fetal life is dependent on increasing BAT cell volume and not on changes in ouabain sensitive respiration. In contrast, the maturation of stimulated respiration is largely independent of changes in cell volume but is dependent on changes in both ouabain sensitive and insensitive respiration.

\section{Abbreviations}

ANOVA, analysis of variance

BAT, brown adipose tissue

KRB, Krebs-Ringer bicarbonate buffer

KRBA, KRB containing $4 \%$ bovine serum albumin

NE, norepinephrine

Recently we characterized the development of in vitro basaland catecholamine-stimulated respiration in isolated brown adipose tissue (BAT) cells from fetal and newborn rabbits (12). Our studies demonstrated that there is a continuous increase in basal
BAT cell respiration from 24 days gestation in the fetus to 10 days of age in the newborn. The increase in stimulated BAT respiration, however, occurs almost entirely during fetal life with only a small increase occurring after birth. These changes in cell respiration were associated with an increase in BAT cell size and mitochondrial enzyme activity.

The present investigation was designed to further clarify the ontogenesis of BAT cell thermogenesis. First, because our previous study demonstrated a developmental increase in BAT cell size, we examined the relationship between BAT cell volume and cell respiration during development. Second, because catecholamineinduced thermogenesis in BAT from adult animals is inhibited by ouabain (a specific inhibitor of sodium transport) (8), we evaluated developmental changes in BAT sodium-potassium dependent adenosine triphosphatase [( $\mathrm{Na} / \mathrm{K}$ ATPase) (E.C.3.6.1.3)] enzyme activity as well as the effect of ouabain on respiration.

\section{MATERIALS AND METHODS}

Newborn studies. Newborn animals were obtained from predelivered litters supplied with nursing does by a local rabbitry. Lactating does with their litters were housed in kindling cages at an environmental temperature of $20-21^{\circ} \mathrm{C}$ and were allowed free access to rabbit chow and water.

Fetal studies. Date bred pregnant New Zealand White rabbits were obtained from a local source. Fetuses were removed by hysterotomy immediately after the doe was sacrificed with an intravenous injection of $2 \mathrm{ml}$ of a concentrated solution of pentobarbital $(360 \mathrm{mg} / \mathrm{ml})$.

Cell isolation. After the animals were sacrificed by decapitation, BAT was removed from the interscapular and pericervical deposits, pooled from four to six animals in each litter, and rinsed in Krebs-Ringer bicarbonate buffer (KRB) containing 4\% bovine serum albumin (KRBA), $136 \mathrm{mM} \mathrm{NaCl}, 4.7 \mathrm{mM} \mathrm{KCl}, 1.3 \mathrm{mM}$ $\mathrm{CaCl}_{2}, 1.2 \mathrm{mM} \mathrm{MgSO}_{4}, 1.2 \mathrm{mM} \mathrm{KH}_{2} \mathrm{PO}_{4}$, and $4.7 \mathrm{mM} \mathrm{NaHCO}_{3}$. The buffer had been gassed previously with $1 \% \mathrm{CO}_{2}$ and $99 \% \mathrm{O}_{2}$ at $37^{\circ} \mathrm{C}$ and adjusted to $\mathrm{pH} 7.2$ with $3 \mathrm{M}$ Tris base. After collagenase digestion, brown adipocytes were isolated in the same buffer, as previously described (12).

Measurement of respiration. After the final cell suspension was adjusted to the appropriate concentration via counting in a hemocytometer, an aliquot was placed in the outer well of Warburg vessels containing KRBA with or without ouabain $(1 \mathrm{mM})$ at room temperature. The center well of each flask contained $0.4 \mathrm{ml}$ of diethanolamine and thiourea (19) and a filter paper wick. The side arm contained either $0.1 \mathrm{ml} \mathrm{KRB}$ or norepinephrine (NE) diluted in KRB. The flasks were placed on a Gilson differential respirometer, allowed to equilibrate for $30 \mathrm{~min}$ at $37^{\circ} \mathrm{C}$, tipped, and equilibrated for another $15 \mathrm{~min}$. Either basal ( \pm ouabain) or catecholamine-stimulated ( \pm ouabain) oxygen consumption then was measured over the next $60 \mathrm{~min}$ at $10 \mathrm{~min}$ intervals. Oxygen consumption was linear for this time interval indicating continuing 
Table 1. Brown adipose tissue cell volume, basal respiration and norepinephrine- $\left(10^{-6} \mathrm{M}\right)$-stimulated respiration in fetal and newborn rabbits ${ }^{1}$

\begin{tabular}{lccc}
\hline & & \multicolumn{2}{c}{$\begin{array}{c}\text { Cell respiration } \\
\left(\mu \mathrm{l} \mathrm{O}_{2} / 10^{6} \text { cells } \cdot \mathrm{h}\right)\end{array}$} \\
\cline { 3 - 4 } \multicolumn{1}{c}{ Age } & $\begin{array}{c}\text { Cell volume } \\
(\mathrm{pl})\end{array}$ & \multicolumn{1}{c}{ Basal } & Stimulated \\
\hline 24 day fetal & $4.6 \pm 0.5$ & $12.9 \pm 1.6$ & $41.7 \pm 6.6$ \\
31 day fetal & $31.3 \pm 2.6$ & $47.2 \pm 5.5$ & $845 \pm 141$ \\
10 day newborn & $34.7 \pm 4.0$ & $89.0 \pm 6.8$ & $836 \pm 78.3$ \\
\hline
\end{tabular}

${ }^{1}$ Results given as arithmetic mean \pm S.E.

cell viability. The final NE concentration in the incubation flasks was $10^{-6} \mathrm{M}$ in a total volume of $3 \mathrm{ml}$. Preliminary experiments had demonstrated that this concentration produced maximal stimulation of BAT cells from both fetal and newborn animals.

The rate of oxygen consumption was determined from the slope of the computer analyzed linear regression line relating the amount of oxygen consumed to time using the method of least mean squares. Results are expressed on the basis of cell number $\left(\mu \mathrm{O}_{2} /\right.$ $10^{6}$ cells $\left.\cdot h\right)$.

Cell volume for each cell suspension was determined after the cells were fixed in $15 \%$ buffered formalin. The diameters of 50 cells were measured using the 40 power objective of a binocular microscope with a grid on the 10 power eyepiece. The cell volume was computed using the formula of Goldrick (5):

$$
\text { Volume }=\frac{\pi}{6}\left(\mathrm{X}^{-2}+3 \text { S.D. }{ }^{2}\right) \overline{\mathrm{X}}
$$

where $\overline{\mathrm{X}}$ (and S.D.) represents the mean (and standard deviation) diameter of the cells in microns. Comparison of fresh and fixed cells failed to demonstrate any effect of the fixation technique on cell diameter.

Four litters of animals were studied at 24 and 31 days gestation and at 10 days of postnatal age.

$\mathrm{Na} / \mathrm{K}$ ATPase activity. BAT was homogenized in $0.25 \mathrm{M}$ sucrose containing $1.24 \mathrm{mM}$ EGTA and $10 \mathrm{mM}$ Tris $(\mathrm{pH}=7.2)$. The homogenates were centrifuged at $1000 \times \mathrm{g}$ for $10 \mathrm{~min}$ and the resultant supernatants were frozen awaiting further analysis. $\mathrm{Na} /$ $\mathrm{K}$ ATPase activity was determined as the difference between phosphate ion hydrolyzed from ATP with and without ouabain $(1 \mathrm{mM})$ in a buffered medium containing $125 \mathrm{mM} \mathrm{NaCl}, 12.5 \mathrm{mM}$ $\mathrm{KCl}, 5 \mathrm{mM} \mathrm{MgCl}_{2}, 24 \mathrm{mM}$ Tris $(\mathrm{pH}=7.4), 5 \mathrm{mM} \mathrm{NaN}_{3}$ and 3 $\mathrm{mM}$ ATP. Phosphate was determined using a modification of the method of Fiske and Subbarow (4). Na/K ATPase activity is expressed as $\mu$ mole $\mathrm{Pi} / \mathrm{mg}$ protein.h. Activity was measured in BAT homogenates from six animals at each gestational and postnatal age.

Statistical analysis. The interrelationship between respiration and cell volume and its effect on the variation of respiration with age was evaluated by analysis of variance (ANOVA) followed by analysis of covariance (20) after logarithmic transformation of the respiration data. Adjusted (for cell volume) means were then compared by $F$ test (20).

The cell volume and enzyme data were analyzed by ANOVA without transformation followed by the Student-Newman-Keuls test (17).

\section{RESULTS}

Cell volume (Table 1): Mean ( \pm S.E.) cell volume increased 7 fold from $4.6 \pm 0.5 \mathrm{pl}$ at 24 days gestation to $31.3 \pm 2.6 \mathrm{pl}$ at 31 days. No further significant increase was observed at 10 days of postnatal age.

Basal respiration. Basal cell respiration increased significantly from 24 days gestation to 10 days postnatal age (ANOVA, $\mathrm{F}=$ 73.7, $P<0.001$ ) (Table 1). There was a significant positive correlation between basal cell respiration and cell size $(r=0.93$, $P<0.01$ ); however, analysis of covariance demonstrated that basal cell respiration remained significantly different in the three experimental groups when changes in cell volume were considered $(\mathrm{F}=8.44, P<0.02)$. Log basal respiration varied 0.0190 with each unit change in cell volume. After adjustment for variation in cell size, basal respiration at 24 and 31 days fetal age were not significantly different $(P>0.05)$, whereas basal respiration at 10 days postnatal age was greater than that in either of the two fetal groups $(P<0.025)$.

Although ouabain suppressed basal respiration in nine of the 13 cell preparations $(5 / 5$ at 24 days, $1 / 4$ at 31 days and $3 / 4$ at 10 days postnatal), this response was quite variable (ranging from 6\%-48\% suppression) and was not significant by paired $t$ test (data not shown). In four of the cell preparations (3/4 at 31 days and $1 / 4$ at 10 days postnatal), ouabain increased basal respiration from $5 \%$ to $67 \%$.

$N E$-stimulated respiration. Stimulated cell respiration increased significantly from 24 days to 31 days gestation (Table 1). No further significant increase was observed at 10 days of postnatal age (ANOVA, $\mathrm{F}=129, P<0.001$ ). There was a significant positive correlation between stimulated respiration and cell size $(r=0.92, P<0.01)$. Analysis of covariance demonstrated that when changes in cell volume were considered, NE-stimulated cell respiration was still significantly different in the three groups $(\mathrm{F}$ $=13.8, P<0.005)$. Log-stimulated respiration varied 0.0012 for each unit change in cell volume. After adjustment for cell size, stimulated respiration was significantly lower in the 24 day fetuses than in the other two age groups $(P<0.005)$; stimulated respiration in the 31 day fetal and 10 day postnatal animals were similar.

Ouabain suppressed NE-stimulated respiration in all four cell preparations in each group of animals (Fig. 1). Mean ( \pm S.E.)

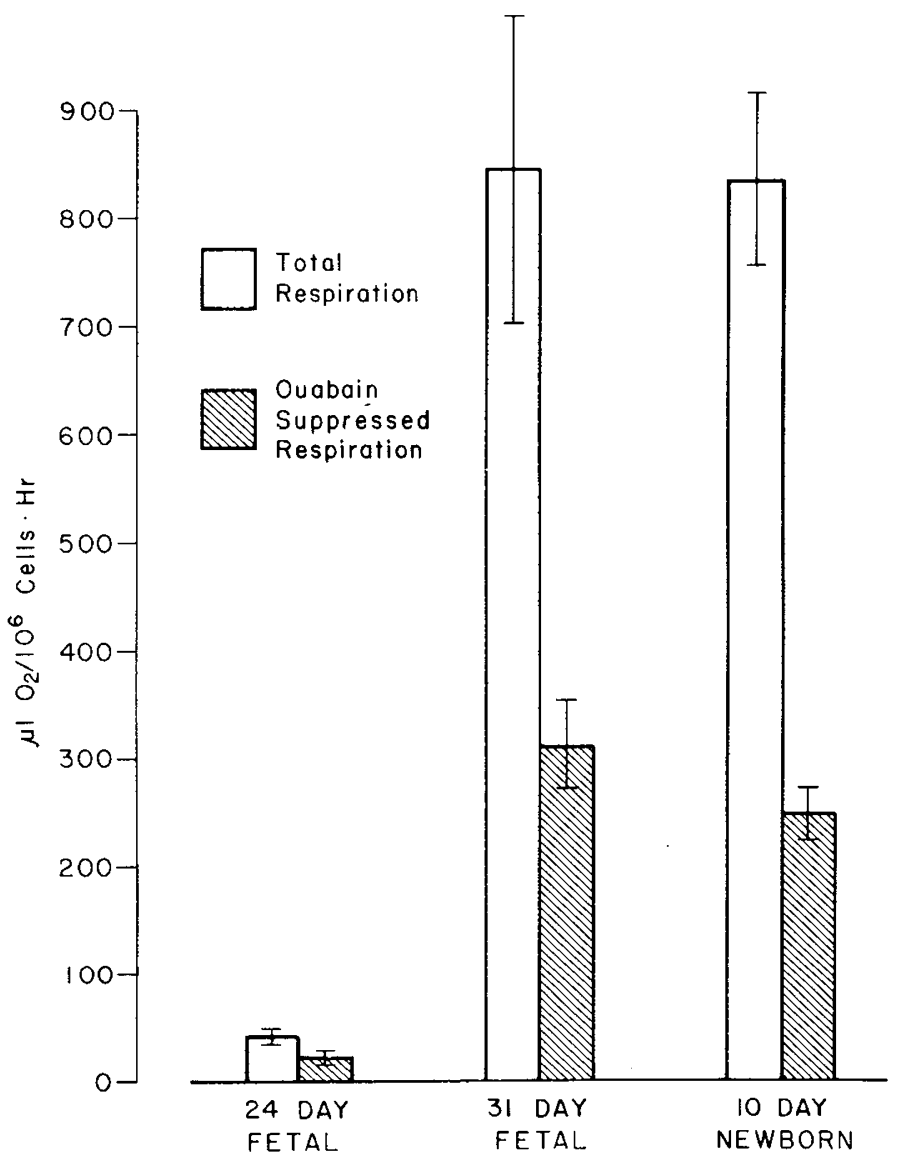

Fig. 1. Catecholamine-stimulated respiration with and without ouabain suppression in brown adipose tissue cells isolated from fetal animals at 24 and 31 days gestation and newborns at 11 days of age. Stimulated respiration increases significantly from 24-31 days gestation with no further increase after birth. Ouabain-suppressed, catecholamine-stimulated respiration by $42.8 \pm 4.4 \%$ at 24 days gestation, $61.9 \pm 2.9 \%$ at 31 days gestation and $69.9 \pm 1.6 \%$ at 10 days postnatal age (ANOVA, $P<$ 0.001 ). See text for further details. 
suppression increased significantly from $42.8 \pm 4.4 \%$ at 24 days gestation to $61.9 \pm 2.9 \%$ at 31 days and $69.9 \pm 1.6 \%$ at 10 days of postnatal age $(P<0.001)$. The latter two mean values were not significantly different.

Residual respiration in the presence of ouabain varied from a mean ( \pm S.E.) of $24.0 \pm 4.3 \mu \mathrm{l} \mathrm{O} 2 / 10^{6}$ cells $\cdot h$ at 24 days of age to $312 \pm 41 \mu 1 \mathrm{O}_{2} / 10^{6}$ cells $\cdot \mathrm{h}$ at 31 days and $250 \pm 24 \mu 1 \mathrm{O}_{2} / 10^{6}$ cells. $\mathrm{h}$ at 10 days postnatal. The difference between total respiration and respiration in the presence of ouabain increased from $17.8 \pm$ $3.6 \mu 1 \mathrm{O}_{2} / 10^{6}$ cells. $\mathrm{h}$ at 24 days to $533 \pm 104 \mu \mathrm{l} \mathrm{O} / 10^{6}$ cells $\cdot \mathrm{h}$ at 31 days and $561 \pm 51 \mu \mathrm{l} \mathrm{O} 2 / 10^{6}$ cells $\cdot h$ at 10 days of postnatal age. For both measurements (ouabain-suppressed and residual respiration in the presence of ouabain) mean results in the 31 day fetal animals and the 10 day old newborns were similar and both values were significantly greater than in the 24 day fetal animals $(P<0.001)$. Analysis of covariance demonstrated that these changes were still significant after correction for changes in cell volume $(P<0.01$ for both $)$.

$\mathrm{Na} / \mathrm{K}$ ATPase activity. $\mathrm{Na} / \mathrm{K}$ ATPase enzyme activities were significantly different in the three groups of animals $(P<0.001)$. Activity increased from a mean of $0.210 \pm 0.037 \mu$ mole $\mathrm{Pi} / \mathrm{mg}$ protein. $\mathrm{h}$ at 24 days gestation to $0.334 \pm 0.031 \mu \mathrm{mole} \mathrm{Pi} / \mathrm{mg}$ protein $\mathrm{h}$ at 31 days and to $0.454 \pm 0.032 \mu \mathrm{mole} \mathrm{Pi} / \mathrm{mg}$ protein . $h$ at 10 days postnatal age.

\section{DISCUSSION}

Heat production from brown adipose tissue enables the mammalian newborn to maintain a stable body temperature during a cold stress. In both full term human and rabbit newborns, the maximal response to a cold stress in vivo is fully developed at birth or within the first few days of life $(1,10,11)$. Although the importance of this source of heat production has been well defined in newborn rabbits $(2,9,10)$, there is little information describing the ontogenesis of BAT thermogenesis in the fetus of any species. Therefore, we have attempted to characterize functional development of this metabolically active tissue using isolated brown adipocytes (12).

The first goal of the present study was to assess the relationship between developmental changes in BAT metabolism and changes in BAT adipocyte size. Experiments in white adipocytes have suggested that cell size has a significant influence on cell metabolism (18). Both basal- and catecholamine-stimulated lipolysis demonstrate a positive correlation with increasing cell size (14). In the present study, a significant correlation was demonstrated between both basal- and NE-stimulated respiration and cell volume. Although the variation in basal cell respiration with cell volume is small $(0.0190 \mathrm{log}$ units per each unit change in cell volume), the increase in basal respiration between 24 and 31 days gestation is accountable by the increase in cell size. Basal respiration, however, is increased at 10 days of age even after correction for cell size.

The variation in catecholamine-stimulated respiration with cell volume is even smaller than that for basal respiration $(0.0012 \mathrm{log}$ units per each unit change in cell volume), and correcting for changes in cell size did not alter the developmental pattern of stimulated respiration in the three groups under study. After correcting for cell volume changes, the capacity for catecholaminestimulated BAT cell respiration increases greatly between 24 and 31 days gestation with no further increase after birth. It appears then that BAT cells in the rabbit are competent to respond to cold-stimulated catecholamine release immediately before full term delivery.

The second goal of the present study was to assess the relationship between developmental changes in BAT metabolism and changes in the effect of ouabain on cellular respiration. Previous investigations have documented ouabain suppressible, catecholamine-stimulated (but not basal) respiration in BAT cells from both adult hamsters (7) and rats (3, 6). Fain et al. (3) suggested that ouabain inhibits catecholamine-stimulated respiration pri- marily by inhibiting lipolysis. Recently, however, it has been demonstrated that ouabain inhibits catecholamine-stimulated respiration even when free fatty acids are supplied exogenously to the cell (15). It appears, then, that the suppressive action of ouabain on BAT thermogenesis does not simply reflect modulation of lipolysis. Because ouabain is known to bind specifically to $\mathrm{Na} / \mathrm{K}$ ATPase and inhibit sodium transport across the cell membrane (16), Horwitz (8) has interpreted the effect of ouabain along with much other supporting evidence to indicate that the $\mathrm{Na} / \mathrm{K}$ membrane transport system takes part in the events that result in an increase in cellular respiration during catecholamine stimulation. As pointed out by Horwitz (8) in a recent review, alternate explanations for the inhibitory effect of ouabain do not appear to fit the available data. The predominant effect of ouabain on BAT cell respiration, as on renal and hepatic cell respiration (16), seems to be mediated via inhibition of sodium transport (8). The mechanisms whereby sodium transport is related to catecholaminestimulated respiration in BAT, however, is still not clear. Experimentally then, sodium-transport dependent respiration can be assessed as the difference between total respiration and respiration suppressed by ouabain (16).

In the present investigation, basal BAT respiration was relatively insensitive to ouabain suppression even in 10-day-old animals after basal BAT cell respiration and $\mathrm{Na} / \mathrm{K}$ ATPase activity had increased. This observation is in agreement with earlier results from our laboratory (13) failing to demonstrate an increase in sodium-transport dependent BAT respiration after thyroid hormone treatment in the newborn rabbit. Herd et al. (6) and Fain et al. (3) also failed to demonstrate a significant ouabain effect on basal respiration in BAT from euthyroid rats. These results suggest that sodium transport does not contribute importantly to unstimulated respiration. Furthermore, changes in sodium-transport dependent respiration do not play a part in the perinatal development of basal respiration in the rabbit.

In contrast, catecholamine-stimulated BAT cell respiration was significantly suppressed by ouabain at all ages studied. At 24 days gestation, catecholamine-stimulated respiration was suppressed by ouabain by approximately $40 \%$; by 31 days, suppressibility had increased to $60-70 \%$. Absolute sodium-transport dependent respiration (the difference between total stimulated respiration and respiration in the presence of ouabain) increased several-fold from a mean of $17.8 \pm 3.6 \mu \mathrm{l} \mathrm{O}_{2} / 10^{6}$ cells. $\mathrm{h}$ at 24 days to $533 \pm 104 \mu \mathrm{l}$ $\mathrm{O}_{2} / 10^{6}$ cells $\cdot h$ at 31 days with no further increase at 10 days of age. Nonsodium-potassium-transport-dependent respiration (residual respiration in the presence of ouabain) also increased significantly between 24 and 31 days gestation with no further increase at 10 days of age. These observations imply that changes in both transport dependent and independent respiration are important during ontogenesis of stimulated respiration in BAT.

Our present results suggest that the increase in basal BAT respiration in the rabbit during fetal life is importantly dependent on the increase in BAT cell volume, and that there is little change in transport dependent basal respiration with increasing gestational age. In contrast, the maturation of catecholamine-stimulated respiration in the rabbit fetus is largely independent of changes in cell volume but is associated with significant increases in both ouabain sensitive and insensitive respiration.

\section{REFERENCES AND NOTES}

1. Bruck, K.: Temperature regulation in the newborn infant. Biol. Neonate, 3: 65 (1961).

2. Dawkins, M. J. R. and Hull, D.: Brown adipose tissue and the response of newborn rabbits to cold. J. Physiol., 172: 216 (1964).

3. Fain, J. N., Jacobs, M. D., and Clement-cormier, Y. C.: Interrelationship of cyclic AMP, lipolysis, and respiration in brown fat cells. Am. J. Physiol., 224: 346 (1973).

4. Fiske, C. H. and Subbarow, Y.: The colormetric determination of phosphorus. J. Biol. Chem., 66: 375 (1925).

5. Goldrick, R. B.: Morphological changes in the adipocyte during fat deposition and mobilization. Am. J. Physiol., 212: 777 (1967).

6. Herd, P. A., Hammond, R. P., and Hamolsky, M. W.: Sodium pump activity during norepinephrine-stimulated respiration in brown adipocytes. Am. J. 
Physiol., 224: 1300 (1973)

7. Horwitz, B. A.: Ouabain-sensitive component of brown fat thermogenesis. Am. J. Physiol., 224: 352 (1973).

8. Horwitz, B. A.: Cellular events underlying catecholamine-induced thermogenesis: cation transport in brown adipocytes. Fed. Proc., 38: 2170 (1979).

9. Hull, D. and Segall, M. M.: The contribution of brown adipose tissue to heat production in the new-born rabbit. J. Physiol., 181: 449 (1965).

10. Hull, D. and Segall, M. M.: Sympathetic nervous control of brown adipose tissue and heat production in the new-born rabbit. J. Physiol., 181: 458 (1965).

11. Hull, D.: Oxygen consumption and body temperature of new-born rabbits and kittens exposed to cold. J. Physiol., 177: 192 (1965).

12. Klein, A. H. and Jenkins, J. J.: Ontogenesis of brown adipose tissue thermogenesis in the rabbit. Metabolism, 30:654 (1981).

13. Klein, A. H., Jenkins, J. J., Reviczky, A., and Fisher, D. A.: Thyroid hormone sensitive brown adipose tissue respiration in the newborn rabbit. Am. J. Physiol., 241: In press (1981)

14. Ogundige, O. O. and Bray, G. A.: The influence of diet and fat cell size on glucose metabolism, lipogenesis, and lipolysis in the rat. Horm. Metab. Res., 6 : 351 (1974).

15. O'Donnell, M. E. and Horwitz, B. A.: Effect of butyrate on ouabain-sensitive respiration of hamster brown adipocytes. Am. J. Physiol., 242: In press (1982).

16. Smith, T. J. and Edelman, I. S.: The role of sodium transport in thyroid

Copyright $\odot 1983$ International Pediatric Research Foundation, Inc. $0031-3998 / 83 / 1703-0220 \$ 02.00 / 0$ thermogenesis. Fed. Proc., 38: 2150 (1979).

17. Sokal, R. R. and Rohlf, F. J.: Biometry, The Principles and Practice of Statistics in Biological Research, pp. 204-252 (W. H. Freeman and Co., San Francisco, 1969).

18. Stern, J. S. and Johnson, P. R.: Size and number of adipocytes and their implications. In: H. Katzen and R. Mahler: Diabetes, Obesity and Vascular Disease, Part I. Advances in Modern Nutrition, Vol. II, Part I, pp. 303-304 (John Wiley and Sons, New York, 1978).

19. Umbreit, W. W., Burris, R. H., and Stauffer, J. F.: Manometric and Biochemical Techniques, pp. 44-47 (Burgess Publishing Co., Minneapolis, 1972).

20. Winer, B. J.: Statistical Principles in Experimental Design, pp. 752-812 (McGrawHill Book Company, New York, 1971).

21. We would like to acknowledge the invaluable laboratory assistance of Anita Reviczky and Jennifer Jenkins and the secretarial assistance of Mary Towles.

22. Recipient of Research Career Development Award HD-00293 from the National Institute of Child Health and Human Development.

23. Requests for reprints should be addressed to: Dr. Alan H. Klein, Building A-17, Harbor-UCLA Medical Center, 1000 W. Carson Street, Torrance, CA 90509.

24. This work was supported by Public Health Service Grants HD-13084 and HD04270 from the National Institute of Child Health and Human Development. 25. Received for publication August 4, 1981.

26. Accepted for publication June 1, 1982. 